\title{
PROFIL PENDERITA ALERGI DENGAN HASIL SKIN PRICK TEST TDR POSITIF DI POLIKLINIK ALERGI-IMUNOLOGI SMF ILMU PENYAKIT DALAM BLU RSUP PROF. DR. R. D. KANDOU MANADO PERIODE JANUARI 2010 - OKTOBER 2012
}

\author{
${ }^{1}$ Randy Manapa \\ ${ }^{2}$ Greta Wahongan \\ ${ }^{2}$ Janno Bernadus \\ ${ }^{1}$ Mahasiswa Fakultas Kedokteran Universitas Sam Ratulangi Manado \\ ${ }^{2}$ Bagian Parasitologi Fakultas Kedokteran Universitas Sam Ratulangi Manado \\ Email: randy_manapa@yahoo.co.id
}

\begin{abstract}
House Dust Mites (HDM) is one of the allergen that triggers allergic reactions, such as asthma, atopic dermatitis, allergic rhinitis, and conjunctivitis, also it could happen to anyone. One of the common ways to do an allergic test, is Skin Prick Test, and this kind of test often performed in hospital. The aim of this study is to know the profile of patients with positive result in Skin Prick Test of HDM. This is a descriptive retrospective study. Subject of this study is medical records of all the patients that diagnosed as allergy with positive results in Skin Prick Test of HDM in Allergy-Immunology department of Prof. Kandou hospital Manado from January 2010 - October 2012. The data is then processed in the form of tables/graphs that are included based on frequency of year of occurrence, sex, age, occupation, and diagnose. It is included that the number of patients who met the study criteria are 119 patients, with the highest peak in the year 2010 (39.5\%), women patients are more than males (53.8\%), the largest age group is $51-60$ years $(29,4 \%)$, most jobs are civil servants $(26.0 \%)$, and bronchial asthma (28.6\%) is the highest diagnosis.
\end{abstract}

Keywords: House Dust Mites, allergy, Skin Prick Test.

\begin{abstract}
Abstrak: Tungau Debu Rumah (TDR) merupakan salah satu alergen pencetus terjadinya reaksi alergi, seperti serangan asma, dermatitis atopik, rhinitis alergi dan konjungtivitis dan bisa terjadi pada siapa saja. Salah satu cara yang umum dilakukan untuk pemeriksaan alergi terhadap TDR adalah Skin Prick Test, dan jenis pemeriksaan ini banyak dilakukan di rumah sakit. Tujuan dari penelitian ini adalah untuk mengetahui gambaran profil penderita dengan hasil Skin Prick Test TDR positif. Penelitian bersifat deskriptif retrospektif. Subjek penelitian adalah rekam medis dari semua penderita yang terdiagnosa sebagai alergi dengan Skin Prick Test TDR positif di poliklinik alergi-imun RSUP Prof. Kandou Manado periode Januari 2010-Oktober 2012. Data kemudian diolah dalam bentuk tabel/grafik yang mencakup frekuensi berdasarkan tahun kejadian, jenis kelamin, umur, pekerjaan, dan diagnosa. Jumlah penderita yang memenuhi kriteria penelitian sejumlah 119 penderita dengan puncak tertinggi pada tahun 2010 (39,5\%), perempuan lebih banyak dari laki-laki (53,8\%), kelompok umur terbanyak pada 51 - 60 tahun (29,4\%), pekerjaan terbanyak adalah PNS (26,0 \%), dan Asma Bronkial (28,6\%) adalah diagnosis terbanyak.
\end{abstract}

Kata kunci: Tungau Debu Rumah, Alergi, Skin Prick Test

Tungau Debu Rumah termasuk dalam filum Arthropoda, kelas Arachnida, ordo Acari, subordo Astigmata, dan family Pyrolyphidae.
Famili Pyroglyphidae terdiri atas 16 genus dan 46 spesies $(1,2)$. Voorhost et al (1969) mendeskripsikan TDR sebagai berikut, yaitu 
besar 0,3 $\mathrm{mm}$ dan lebar $0,2 \mathrm{~mm}$, dan badan simetris bilateral. Jenis jantan lebih kecil ukurannya daripada yang betina, dan mempunyai 6 kaki pada stadium larva, dan 8 kaki pada stadium dewasa (1). TDR memerlukan tempat yang hangat, lembab dan gelap dalam pertumbuhan dan berkembang biak, dimana tungau memerlukan suhu ruangan $25-30^{\circ} \mathrm{C}$ dan kelembaban udara 70-80\% untuk hidupnya. Makanan TDR adalah skuama, daki, dan sisa makanan. Dalam satu hari manusia menghasilkan skuama 0,5 - $1 \mathrm{~g}$, dan $1 \mathrm{mg}$ skuama dapat mencukupi kebutuhan makan satu tungau selama 20 bulan. TDR hidup bercampur dengan debu yang terdapat di kasur, karpet, sofa, maupun peralatan rumah tangga lainnya, namun kasur merupakan tempat yang paling disukai tungau karena di tempat tersebut tersedia sumber makanan utama berupa epitel kulit manusia dan jamur (1-2).

TDR merupakan salah satu faktor pencetus alergi, dan bagian tubuh tungau yang mengandung alergen adalah kutikula, saluran cerna, dan organ seksual. Menurut Momcouglu dan Rufli (1979), antigen yang terdapat dalam $D$. pteronyssinus terutama di saluran cerna dan di kutikula. Makanan yang masuk ke usus diekskresikan sebagai antigen yang kuat. Selain tubuh TDR, telah dibuktikan bahwa feses TDR juga mempunyai sifat antigenik. Antigen yang berasal dari tubuh TDR masuk ke dalam tubuh mausia melalui penetrasi kulit, sedangkan yang berasal dari feses masuk ke tubuh manusia melalui inhalasi (1). Gejala alergi yang disebabkan TDR dapat berupa dermatitis atopik/eczema, rhinitis alergi, konjungtivitis, dan asma. Meskipun demikian, selain asma biasanya gejala lain yang muncul sering disepelekan penderita sehingga tidak mencari pertolongan, dan hanya mencari pertolongan disaat gejala sudah memberat seperti asma. Asma dapat diinisiasi dan diprovokasi oleh alergen yang terdapat setiap harinya di sekeliling kita, misalnya TDR, kecoa, bulu kucing dan asap rokok (3).

Penelitian di Hongkong menyebutkan bahwa prevalensi dermatitis atopik pada anak usia 13-14 tahun sebanyak 3,3\% dan anak usia 6-7 tahun sekitar 4,2\%. Prevalensi asma di Inggris pada tahun 1999-2004 meningkat dibandingkan 1992-1998 sebanyak $>20 \%$ pada anak usia 6-7 tahun dan $>25 \%$ pada anak usia 13-14 tahun (4). Penelitian di Brazil, prevalensi alergi berdasarkan kuesioner ISAAC yaitu usia 6-7 tahun adalah $17 \%$ dan usia 13-14 tahun adalah $25 \%{ }^{15}$ Prevalensi alergi berdasarkan kuesioner ISAAC pada anak usia 6-7 tahun dan usia 13-14 tahun di Kroasia adalah asma sebanyak 9,7\% dan 8,4\%, rhinitis alergik sebanyak 16,9\% dan 17,5\%, dermatitis atopic sebanyak 5,4\% dan 3,4\% (5).

Skin prick test adalah salah satu jenis tes kulit sebagai alat diagnosis yang banyak digunakan oleh para klinisi untuk membuktikan adanya IgE spesifik (misalnya kotoran TDR) yang terikat pada sel mastosit kulit. Terikatnya IgE pada mastosit ini menyebabkan keluarnya histamine dan mediator lainnya yang dapat menyebabkan vasodilatasi dan peningkatan permeabilitas pembuluh darah akibat timbulnya flare/ kemerahan dan wheal/bentol pada kulit tersebut (6).

\section{METODE PENELITIAN}

Penelitian ini bersifat deskriptif retrospektif. Populasi penelitian adalah seluruh status rekam medis penderita di poliklinik alergi-imunologi RSUP Prof. Kandou Manado. Sampel penelitian adalah seluruh rekam medis penderita alergi dengan Skin Prick Test TDR positif dari Januari 2010 Oktober 2012

Penelitian dilakukan di RSUP Prof. Kandou Manado sejak November Desember 2012. Penelitian ini bertujuan untuk memberi gambaran profil penderita alergi dengan Skin Prick Test TDR positif yang memeriksakan diri ke RSUP Prof. Kandou Manado pada Januari 2010 Oktober 2012.

\section{HASIL PENELITIAN DAN BAHASAN}

Pada penelitian ini, dari Januari 2010Oktober 2012 didapatkan 119 penderita dengan Skin Prick Test TDR positif yang dijadikan sampel penelitian. Dari jumlah 
tersebut, diklasifikasikan dalam beberapa tabel berikut:

\section{Distribusi menurut tahun periksa}

Tabel 1. Distribusi pasien berdasarkan tahun periksa

\begin{tabular}{ccc}
\hline Periode & Jumlah & $\begin{array}{c}\text { Persentase } \\
\text { (\%) }\end{array}$ \\
\hline Jan - Des & 47 & 39,5 \\
2010 & & 37,0 \\
Jan - Des & 44 & 23,5 \\
2011 & & 100 \\
Jan - Okt & 28 & \\
2012 & 119 &
\end{tabular}

Pada Tabel 1 diatas, didapati bahwa dalam periode hampir 3 tahun tersebut terdapat 119 total kasus penderita Alergi dengan Skin Prick Test Tungau Debu Rumah Positif (+). Prevalensi angka kejadian terlihat adanya penurunan, dimana dari 47 kasus (39,5\%) di tahun 2010 turun menjadi 44 kasus (37,0\%) di tahun 2011, dan pada periode Januari-Oktober 2012 turun lagi menjadi 28 kasus (23,5\%). Hal ini kemungkinan disebabkan oleh meningkatnya tingkat pengetahuan masyarakat mengenai alergi, dan diikuti juga dengan meningkatnya tingkat kesadaran masyarakat akan kebersihan.

\section{Distribusi menurut jenis kelamin}

Tabel 2. Distribusi pasien alergi berdasarkan jenis kelamin

\begin{tabular}{ccc}
\hline $\begin{array}{c}\text { Jenis } \\
\text { Kelamin }\end{array}$ & Jumlah & $\begin{array}{c}\text { Persentase } \\
(\mathbf{\%})\end{array}$ \\
\hline Laki- laki & 55 & 46,2 \\
Perempuan & 64 & 53,8 \\
\hline Total & 119 & 100 \\
\hline
\end{tabular}

Pada Tabel 2, terlihat bahwa jumlah perempuan (64 kasus, 53,8\%) lebih tinggi daripada jumlah laki-laki (55 kasus, 46,2\%). Berdasarkan penelitian di AS, didapatkan bahwa penderita perempuan lebih banyak daripada pria (7). Namun pada penelitian di India, menunjukkan hasil yang berlawanan, dimana laki-laki lebih banyak daripada perempuan (8). Hubungan antara jenis kelamin dengan tingkat kejadian alergi sendiri belum diketahui secara pasti.

\section{Distribusi menurut kelompok umur}

Tabel 3. Distribusi pasien alergi berdasarkan kelompok umur

\begin{tabular}{ccc}
\hline Umur & Jumlah & Persentase(\%) \\
\hline$<21$ & 14 & 11,8 \\
$21-30$ & 6 & 5,0 \\
$31-40$ & 13 & 10,9 \\
$41-50$ & 29 & 24,4 \\
\hline $51-60$ & 35 & 29,4 \\
\hline
\end{tabular}

Pada Tabel 3, didapatkan insiden terbanyak pada usia 51-60 tahun sebesar 35 kasus (29,4\%), diikuti urutan kedua terbanyak pada usia 41-50 tahun sebesar 29 kasus (24,4\%). Disini terlihat bahwa insiden terbanyak tejadi pada usia lanjut. Kepustakaan menyebutkan, paparan yang berulang dapat memicu timbulnya alergi pada seseorang, maka semakin bertambahnya usia seseorang, kemungkinan akan terkena alergi semakin meningkat pula (9). Pada penelitian di AS sendiri menunjukkan para penderita alergi terbanyak adalah dari rentang usia 35 - 64 tahun (8).

\section{Distribusi menurut pekerjaan}

Tabel 4. Distribusi pasien alergi menurut pekerjaan

\begin{tabular}{ccc}
\hline Pekerjaan & Jumlah & $\begin{array}{c}\text { Persentase } \\
(\%)\end{array}$ \\
\hline PNS & 31 & 26,0 \\
Pensiunan & 23 & 19,3 \\
IRT & 22 & 18,5 \\
Swasta & 11 & 9,2 \\
Mahasiswa & 7 & 5,9 \\
Siswa & 7 & 5,9 \\
Petani & 2 & 1,7 \\
Lain-lain & 4 & 3,6 \\
Tidak ada & 12 & 10,1 \\
data & & \\
\hline Total & 119 & 100 \\
\hline
\end{tabular}


Pada Tabel 4 terlihat bahwa PNS menempati urutan teratas yakni sebesar 31 orang (26,0\%), diikuti oleh pensiunan 23 orang (19,3\%), dan IRT 22 orang (18,5\%). Alasan mengapa PNS menempati urutan teratas adalah karena rumah sakit tersebut merupakan rumah sakit tujuan bagi para pengguna ASKES yang diikuti seluruh PNS. Dibanding PNS, pensiunan dan IRT pada umumnya menghabiskan banyak waktu di rumah, dan sering kontak dengan perabotan rumah, seperti sofa dan kasur dan beresiko untuk terkena paparan Tungau Debu Rumah, dimana TDR banyak terdapat di kasur dan sofa $(1,9)$.

\section{Distribusi menurut diagnosa}

Tabel 5. Distribusi pasien alergi menurut diagnosa

\begin{tabular}{ccc}
\hline Diagnosa & Jumlah & $\begin{array}{c}\text { Persentase } \\
\text { (\%) }\end{array}$ \\
\hline Alergi & 14 & 11,8 \\
Makanan & & \\
Alergi Obat & 20 & 16,8 \\
Asma & 34 & 28,6 \\
Bronchiale & & \\
Dermatitis & 10 & 8,4 \\
Alergik & & \\
TB Paru & 6 & 5,0 \\
Rhinitis & 5 & 4,2 \\
Alergi & & \\
Urtikaria & 4 & 3,4 \\
Bronchitis & 4 & 3,4 \\
Asma & 3 & 2,5 \\
Intermiten & & 9,2 \\
Lain-lain & 11 & 6,7 \\
Tidak ada & 8 & \\
data & & 100 \\
\hline Total & 119 &
\end{tabular}

Pada Tabel 5, dalam hasil penelitian terlihat bahwa diagnosa terbanyak adalah Asma Bronchial dengan 34 kasus (28,6\%), hal ini didukung oleh WAO yang menyebutkan bahwa Asma Bronchial merupakan jenis alergi tersering yang menyebabkan penderita memeriksakan diri pada petugas medis (7). Alergi obat (20 kasus, 16,8\%) dan alergi makanan (14 kasus, 11,8\%) juga merupakan penyebab penderita memeriksakan diri ke petugas medis. Sebelum melakukan terapi obat (terutama terapi obat jangka panjang atau golongan obat tertentu seperti penisilin), para dokter biasanya merujuk pasien untuk melakukan tes alergi obat.

\section{SIMPULAN}

Dari data-data diatas dapat dilihat bahwa profil penderita alergi dengan Skin Prick Test TDR positif di RSUP Prof. Kandou adalah lebih banyak wanita, usia 51-60 tahun, umumnya bekerja sebagai PNS, dan jenis alerginya adalah asthma bronchial yang terbanyak diderita, serta terjadi penurunan dalam 3 tahun terakhir.

\section{UCAPAN TERIMA KASIH}

Ditujukan kepada dr. Eko Surachtmanto Sp.PD-KAI yang telah memberikan banyak masukkan mengenai Alergi-Immunologi, dan telah mengizinkan penulis untuk bisa melakukan penelitian di bagian Alergi - Imunologi. Ucapan terima kasih juga ditujukan kepada dr.Greta J. P. Wahongan, M.Kes dan dr. Janno Bernadus, M.Biomed sebagai dosen pembimbing 1 dan pembimbing 2 sekaligus sebagai penguji 1 dan penguji 2 yang telah memberikan banyak masukan dan saran, serta pihak-pihak yang secara langsung atau tidak langsung memberikan gagasan dan ide kepada penulis sehingga dapat menyelesaikan artikel ini.

\section{DAFTAR PUSTAKA}

1. Sungkar S. Aspek Biomedis Tungau Debu Rumah. Tinjauan Pustaka. Maj Kedokt Indon. Vol 54 2004;no 6:224-33.

2. Nadchatram M. House dust mites, our intimate associates. Tropical biomedicine. Vol 22 2005;23-37.

3. Dust mite allergens and asthma: a worldwide problem. Bulletin of World Health Organization.1988:769-80.

4. Cunha SSD, Bareto ML, Fiaccone RL, Cooper PJ, Neves NMA, Simoes SDM. Asthma cases in childhood attributed to atopy intropical area in Brazil. Rev Panam Salud Publica.2010;405-11. 
1032 Jurnal e-Biomedik (eBM), Volume 1, Nomor 2, Juli 2013, hlm. 1028-1032

5. Banac S, Tomulic KL, Ahel V, Rozmanic V, Simundic N, Zubovic S, et al. Prevalence of asthma and allergic disease in Croatian children : survey study. Croatian Med J.2004;721-6.

6. Kartikawati H. Tes Cukit (Skin Prick Test) pada Diagnosis Penyakit Alergi. Tinjauan Pustaka. 2007.

7. Jones and Barret Learning. Asthma: A Global Perspective.
8. Aggarwal AN, Chaudhry K, Chhabra SK, D’Souza GA, Gupta1 D, Jindal1 SK, et al. Prevalence and Risk Factors for Bronchial Asthma in Indian Adults: A Multicentre Study. The Indian Journal of Chest Diseases \& Allied Sciences. 2006; Vol. 48:13-22.

9. WAO White Book on Allergy 20112012:Executive Summary. 